\title{
Impact of the company's main budgeting objectives on the evaluation of importance of financial and non-financial indicators
}

\author{
Inta Kotane \\ Rezeknes Augstskola, Research Institute for Regional Studies. \\ Address: Atbrivosanas aleja 115, Rezekne, LV-4601, Latvia. \\ Riga International School of Economics and Business Administration, PhD student. \\ Address: 3 Meža Street, Riga, LV-1048, Latvia
}

\begin{abstract}
Financial planning forms a basis for the company's management and determines the company's objectives; the achievement of these objectives is measured using financial and non-financial indicators. The main budgeting objectives affect the importance of financial and non-financial indicators, thus, contributing to the achievement of the goals. The topicality of the research is determined by the fact that the financial and non-financial indicators have been examined by many authors; however, there exist problems regarding their practical application, since still there is no a consistent approach to the measurement and evaluation of both the financial and non-financial indicators. The study is based on the author's previous theoretical research on the application of financial and nonfinancial indicators in the evaluation of business performance; as a result, the author has established the sets of financial and non-financial indicators that were used in conducting the practical research.

The aim of the current research is to determine the impact of the main company's budgeting objectives on the evaluation of importance of financial and non-financial indicators on the basis of the opinion survey of Latvian business persons and top-level employees. The Internet survey was used in the research, applying a random sampling method.

The research results indicate that the opinions in the groups of respondents regarding the main company's budgeting objectives differ, and the correlations exist among the main budgeting objectives. Comparison of the impact of the main budgeting objectives on the importance level of the financial and non-financial indicators shows that the possible impact is more significant regarding the importance of the financial rather than non-financial indicators.
\end{abstract}

Keywords: budgeting objective, financial indicators, non-financial indicators, importance.

\section{INTRODUCTION}

To describe the results of the business activities, the term "performance" is used in the foreign research and academic literature Lebas considers that the performance is never objective, it is only a way of defining where one wants to go [16]. "Performance", is an interesting concept. "Performance", is not an objective reality out there somewhere waiting to be measured and evaluated. "Performance", is socially constructed reality [1]. Laitinen defines the performance as an ability of an object to produce results in a dimension determined a priori, in relation to a target. Thus it is necessary to have, first, an object whose performance is to be considered; second, a dimension in which one is interested; and, third, a set target for the result [15]. Folan supposes that the performance is governed by the following three priorities: (1) It is always made as per the deemed relevance of an entity to a particular environment (thus, we commonly assess a company on its impact, for example, in a particular market...); (2) It is always made with a relevant objective in mind (thus, we commonly assess a company as per some set future vision on what the company wants to achieve...); (3) It is always reduced to relevant, recognisable characteristics (thus, we commonly assess a company on competitive parameters, such as cost, quality, time, etc., and more harder-to-measure competitive priorities, such as flexibility, or sustainability, because they are relevant and recognisable etc.) [7].

One of the company's priorities is the achievement of the specific aim [7], [26], furthermore, the company is assessed according to its future goals, referring to the targets the company intends to achieve.

It could be concluded that the company's performance can be described as an ability of the company to represent itself to the outside, using the performance indicators that characterise activities and 
achievements of the company in relation to its goals and thus creating an overall opinion about the company.

The analysis of the researches on the frameworks of the performance measurement [6], [7], [18], [21], [22], [24], indicates that the dimensions of the company's performance measurement include financial and nonfinancial indicators. Uyar believes that the performance measurement tools could be classified as traditional including financial measures and new approaches including non-financial measures along with financial ones [23]. The financial and nonfinancial indicators used in the researches on the evaluation of the company's performance reveal their diversity. In the evaluation of the companies' nonfinancial and/or financial performance, various number of the indicators have been used: 3 nonfinancial and 3 financial indicators [27], 11 nonfinancial and 5 financial indicators [5], 6 non-financial and 2 financial indicators [14], 9 non-financial indicators [3], 12 non-financial and 4 financial indicators [2], 5 non-financial and 5 financial indicators [20], 14 non-financial indicators [8], 23 non-financial and 8 financial indicators [19], 10 nonfinancial and 2 financial indicators [4], 12 financial indicators [25] etc. Lack of a united approach to the use of financial and non-financial indicators for evaluation of the company's financial and/or nonfinancial performance leads to the problem of their practical application. The author has carried out an assessment of the financial and non-financial indicators that are used in the evaluation of financial and non-financial performance of the companies, and as a result has established the sets of financial and non-financial indicators that are used in the practical research.

The researches on the companies' performance measurement using financial and non-financial indicators have not been carried out in Latvia; that defines timely character of the research topic.

The aim of the current research is to carry out the assessment of possible impact of the main company's budgeting objectives on the evaluation of significance of financial and non-financial indicators on the basis of the opinion survey of Latvian business persons and top-level employees.

In order to achieve the aim of the research, the following research objectives are defined:

- using the companies' survey results, to assess the impact of the companies' budgeting objectives on the evaluation of importance of the financial and non-financial indicators;

- to draw conclusions.

The object of the research: financial and nonfinancial indicators.

The methods of the research: information analysis and synthesis, method of constructive logics, data grouping and comparison method.

\section{MATERIALS AND METHODS}

The current research is based on the theoretical studies by the author on the use of the financial and non-financial indicators in the evaluation of the business performance [12], [13] and continues the previous practical researches [10], [11]. To approbate the theoretical statements, the author has used the internet survey applying the random sampling method and has surveyed 208 Latvian companies in August and September 2012. The Latvian business persons and top-level employees of the Latvian companies, who are the users of the internal information making various operational and financial decisions, were surveyed: owners and top managers of the companies, heads of the structural units, heads and employees of financial departments. The aim of the survey was to establish the system of indicators for the evaluation of the business performance, which could be used by the managers to evaluate in an integrated way and to control efficiently the financial position of the company in the circumstances of the growing competition. The system of indicators would include both the set of specific financial indicators and nonfinancial indicators that would demonstrate the internal potential and future development possibilities of the company.

In the presentation of the study results, the opinions of the groups of respondents - owners, managers, heads of structural units, heads and staff of financial departments - are compared and assessed. The analysis of the research data was carried out considering four categories of enterprises: all enterprises (the total number of respondents), micro enterprises (1 - 9 employees), small enterprises (10-49 employees) and micro-small enterprises (1 - 49 employees), with the aim to identify possible differences regarding the small enterprises.

The assessment of the significance of the financial and non-financial indicators is based on the evaluation of importance of the financial and non-financial indicators in measurement of the business performance found in the companies' survey. In the survey, the five point Likert scale with a range from 1 ("Not important") to 5 ("Highly important") was used in the questions regarding the importance of financial and non-financial indicators in evaluation of the company's performance.

To establish a correlation among the groups of respondents and their replies, reciprocal correlations among the main budgeting objectives, as well as correlation between the main budgeting objectives and the importance of the financial and non-financial indicators, the Spearman's rank correlation coefficient method was used, as the respondents' responses being analysed are descriptions, and not precise values. Correlation between two questions has been considered, if the result has been statistically significant and the correlation coefficient $r>0.50$. If $r$ 
is smaller, the correlation or relationship is weak or very weak. Considering r, it is possible to evaluate the strength of the relationship. Disregarding size of the sample, if $0<|\mathrm{r}|<0.2$, a correlation is very weak, $0.2 \leq|\mathrm{r}|<0.50$ - correlation is weak, $0.50 \leq|\mathrm{r}|<0.70$ correlation is moderate, $0.7 \leq|\mathrm{r}|<0.90$ - correlation is strong [9]. The result was considered to be statistically significant if $\mathrm{p}<0.05$ or $\mathrm{p}<5.00 \times 10^{-2}$ [17].

In order to examine whether the company's main budgeting objectives affect the importance of the factor groups of financial and non-financial indicators thus contributing to the achievement of the business goals, the regression analysis was conducted determining the impact $\left(\mathrm{R}^{2}\right)$ of each objective to the evaluation of the importance of the factor groups' indicators. The first, a linear regression was carried to identify the impact of the particular budgeting objectives (independent variable) to each factor group (dependent variable). Then, a multiple regression analysis was carried out to establish the overall impact of all company's main budgeting objectives on the factor groups. To verify the mode the importance of financial and non-financial indicators is affected by the company's main budgeting objectives thus fostering achievement of the business goals, the regression analysis was carried out determining an impact of each budgeting objective $\left(\mathrm{R}^{2}\right)$ on the assessment of importance of the financial and nonfinancial indicators. In view of the fact that the regression data is not intended to build the forecast models, only the possible impact $\left(\mathrm{R}^{2}\right)$ and the reliability of the regression model or impact (p) are specified in the research results, considering that the results are statistically reliable if $R^{2} \geq 0,05$ and $p<0.05$.

The survey results are processed and analysed using SPSS and Excel programmes.

\section{RESULTS AND DISCUSSION}

The survey respondents profile shows that, by the position in the company, most of the respondents (47.1\%) are the owners of the companies (Table 1).

To identify the enterprise category (micro, small, medium enterprise or a large company), the average number of employees was used as a criterion. The respondents profile illustrates that according to the average number of employees the largest proportion is comprised by the companies with a number of employees from 1 to $9(55.3 \%)$; according to the main business sector - wholesale and retail trade, repair of motor vehicles and motorcycles $(24.5 \%)$, according to the year of founding - the companies that have been established from 1994 to 2000 (23.1\%), and according to the companies' turnover during the last accounting year - the companies with the net turnover from 10001 to $70000 \mathrm{LVL}$ (until 01.01.2014. 1 EUR = 0.702804 LVL) (30.3\%).
TABLE 1.

PROFILE OF THE RESPONDENTS IN THE COMPANIES' SURVEY (\%)

\begin{tabular}{|c|c|}
\hline \multicolumn{2}{|l|}{ Position of respondents in the company, $\%$} \\
\hline Owners & 47.1 \\
\hline General managers & 24.5 \\
\hline Structural unit managers & 4.3 \\
\hline Financial department managers & 11.5 \\
\hline Staff of financial departments & 12.5 \\
\hline \multicolumn{2}{|l|}{ Average number of employees in the company, $\%$} \\
\hline 1 - 9 employees & 55.3 \\
\hline 10 - 49 employees & 28.8 \\
\hline 50 - 249 employees & 14.4 \\
\hline More than 250 employees & 1.4 \\
\hline \multicolumn{2}{|l|}{ Turnover in the last accounting year, $\%$} \\
\hline Less than $10,000 \mathrm{LVL}$ & 13.9 \\
\hline $10,001-70,000 \mathrm{LVL}$ & 30.3 \\
\hline 70,001 - 200,000 LVL & 18.3 \\
\hline $200,001-500,000 \mathrm{LVL}$ & 8.7 \\
\hline More than 500,000 LVL & 28.8 \\
\hline \multicolumn{2}{|l|}{ Main business sector, $\%$} \\
\hline (A) Agriculture, forestry and fishing & 10.1 \\
\hline (B) Mining and quarrying & 5.8 \\
\hline (C) Manufacturing & 15.9 \\
\hline (F) Construction & 8.7 \\
\hline $\begin{array}{l}\text { (G) Wholesale and retail trade; repair of motor vehicles } \\
\text { and motorcycles }\end{array}$ & 24.5 \\
\hline (S) Other services activities & 14.9 \\
\hline (M) Professional, research and technical services & 5.8 \\
\hline Others & 14.4 \\
\hline \multicolumn{2}{|l|}{ Year of foundation, $\%$} \\
\hline Before 1991 & 10.1 \\
\hline 1991 - 1993 & 21.6 \\
\hline $1994-2000$ & 23.1 \\
\hline $2001-2007$ & 18.8 \\
\hline $2007-2010$ & 16.8 \\
\hline After 2010 & 9.6 \\
\hline
\end{tabular}

To sum up, the respondents have different positions in the companies; the companies represented are of different business sectors, different years of foundation, different average number of employees, and different volume of the net turnover. The author has carried out the statistical analysis and has concluded that there is a statistically reliable difference in all categories of enterprises, $\mathrm{p}<0.05$ and with a probability of $95 \%$ it could be confirmed that the values used by the respondents of different groups to characterize companies significantly differ.

The establishing of sets of the financial and nonfinancial indicators included in the business efficiency evaluation of the companies is affected by the financial planning and controlling practices. The 
financial planning comprises a basis for the company's management and determines the objectives, achievements of which are measured using the financial and non-financial indicators. The respondents' views on what are the company's budgeting goals are summarized in Table 2, demonstrating variety of opinions.

Most of the respondents - company owners in all enterprise categories - consider that the main budgeting goal is $A R(21.2 \%)$. General managers in all enterprise categories are of the same opinion on the main budgeting goals of the company - that is to be IEP (from $14.3 \%$ replies in the micro companies up to $20 \%$ in the small companies). Heads of structural units (15.8\%) of all enterprises deem IEB to be the main budgeting objective. Views of the heads of structural units of micro-small and small companies are split among two budgeting objectives to be considered as the main - IEB and $I T$ comprising $15.4 \%$. Managers of financial departments have the biggest diversity of opinions in comparison with other groups of the respondents: they have named as much as six major budgeting objectives in all enterprise categories. Those are: $A R(27.3 \%)$ in the category of all enterprises, IEP (20\%) in the micro-small enterprises, and proportionally divided opinions in favour of $A R$, $I P, I E B$ and $P D(25 \%)$ in the small enterprises. The heads of financial departments of the micro enterprises identify $I P$ and $I S S$ as the main budgeting objectives $(22.2 \%)$.

TABLE 2.

THE MAIN BUDGETING OBJECTIVES OF THE COMPANIES, \%

\begin{tabular}{|c|c|c|c|c|c|c|c|c|c|c|c|c|c|c|c|c|c|c|c|c|}
\hline \multirow{2}{*}{$\begin{array}{l}\text { The main } \\
\text { budgeting } \\
\text { objectives }\end{array}$} & \multirow{2}{*}{ ن } & \multicolumn{5}{|c|}{ All companies } & \multicolumn{5}{|c|}{ Micro-Small Enterprises } & \multicolumn{5}{|c|}{ Small Enterprises } & \multicolumn{4}{|c|}{ Micro Enterprises } \\
\hline & & $1^{*}$ & $2 *$ & $3 *$ & $4^{*}$ & $5^{*}$ & $1^{*}$ & $2^{*}$ & $3 *$ & $4 *$ & $5 *$ & $1^{*}$ & $2 *$ & $3 *$ & $4 *$ & $5^{*}$ & $1^{*}$ & $2 *$ & $4 *$ & $5^{*}$ \\
\hline $\begin{array}{l}\text { Assessment of } \\
\text { the resources } \\
\text { aiming at the } \\
\text { rational and } \\
\text { efficient } \\
\text { utilization }\end{array}$ & $\mathrm{AR}$ & 19.7 & 13.3 & 5.3 & 27.3 & 24.0 & 20.5 & 12.5 & 7.7 & 13.3 & 24.0 & 25.0 & 15.0 & 7.7 & 25.0 & 27.3 & 19.7 & 10.7 & 11.1 & 21.4 \\
\hline $\begin{array}{l}\text { Increase of net } \\
\text { turnover }\end{array}$ & IT & 7.6 & 10.0 & 10.5 & 4.5 & 8.0 & 7.0 & 10.4 & 15.4 & 6.7 & 8.0 & 6.3 & 10.0 & 15.4 & - & 9.1 & 7.1 & 10.7 & 11.1 & 7.1 \\
\hline $\begin{array}{l}\text { Increase of } \\
\text { profits }\end{array}$ & IP & 10.5 & 10.0 & 10.5 & 9.1 & 18.7 & 10.9 & 12.5 & 7.7 & 13.3 & 18.7 & 12.5 & 15.0 & 7.7 & - & 9.1 & 10.6 & 10.7 & 22.2 & 26.2 \\
\hline $\begin{array}{l}\text { Increase of } \\
\text { efficiency or } \\
\text { profitability }\end{array}$ & IEP & 8.6 & 16.7 & 5.3 & 13.6 & 4.0 & 8.9 & 16.7 & 7.7 & 20.0 & 4.0 & 12.5 & 20.0 & 7.7 & 25.0 & - & 8.3 & 14.3 & - & 7.1 \\
\hline $\begin{array}{l}\text { Increase of } \\
\text { utilization } \\
\text { efficiency of } \\
\text { equity capital } \\
\text { and borrowed } \\
\text { funds }\end{array}$ & IEB & 1.9 & 6.7 & 15.8 & - & 10.7 & 2.0 & 4.2 & 15.4 & - & 10.7 & 6.3 & - & 15.4 & - & 18.2 & 1.2 & 7.1 & 11.1 & 4.8 \\
\hline $\begin{array}{l}\text { Increase of } \\
\text { customers } \\
\text { satisfaction }\end{array}$ & ICS & 11.5 & 10.0 & 10.5 & 9.1 & - & 10.9 & 6.3 & 7.7 & 13.3 & - & 12.5 & - & 7.7 & 25.0 & - & 10.6 & 10.7 & - & - \\
\hline $\begin{array}{l}\text { Increase of } \\
\text { market share }\end{array}$ & IMS & 8.6 & 11.7 & 5.3 & - & 12.0 & 8.9 & 10.4 & 7.7 & - & 12.0 & - & 5.0 & 7.7 & - & 9.1 & 10.6 & 14.3 & - & 14.3 \\
\hline $\begin{array}{l}\text { Increase of } \\
\text { staff } \\
\text { satisfaction }\end{array}$ & ISS & 4.8 & 3.3 & 10.5 & - & 2.7 & 4.0 & 4.2 & 7.7 & - & 2.7 & 6.3 & 5.0 & 7.7 & - & - & 3.5 & 3.6 & 22.2 & 4.8 \\
\hline $\begin{array}{l}\text { Improvement } \\
\text { of products/ } \\
\text { services quality }\end{array}$ & IQ & 8.6 & 10.0 & 5.3 & 13.6 & 8.0 & 7.9 & 12.5 & 7.7 & 13.3 & 8.0 & 12.5 & 1.1 & 7.7 & - & 9.1 & 7.1 & 10.7 & 11.1 & 7.1 \\
\hline $\begin{array}{l}\text { New products/ } \\
\text { services } \\
\text { development }\end{array}$ & PD & 11.5 & 5.0 & 10.5 & 13.6 & 12.0 & 11.9 & 6.3 & 7.7 & 13.3 & 12.0 & - & 10.0 & 7.7 & 25.0 & 18.2 & 14.2 & 3.6 & 11.1 & 7.1 \\
\hline $\begin{array}{l}\text { Improvement } \\
\text { of reputation }\end{array}$ & IR & 6.7 & 3.3 & 10.5 & 9.1 & - & 7.0 & 4.2 & 7.7 & 6.7 & - & 6.3 & 5.0 & 7.7 & - & - & 7.1 & 3.6 & - & - \\
\hline
\end{tabular}

Designations: * 1 - owner, 2 - general manager, 3 - head of structural unit, 4- head of financial department, 5 - staff of financial department

The conformity of opinions is observed among the staff of financial departments in all enterprise categories, except the micro-enterprises, determining

$A R$ as the main budgeting objective $(25.1 \%$ in average); on its turn, the financial department staff of the micro enterprises deems the IP $(26.2 \%)$ as the 
main budgeting goal. The author considers that the main budgeting objectives as named by the respondents, in general, corresponds with the time period, used by the companies to design financial plans for, usually, that is 1 (one) year (an annual budget). In addition, taking into account that approximately $1 / 4$ of the companies do not perform financial planning, it could have happened that part of the respondents have named just prospective budgeting goals of the company.

Summing up the opinions of the respondent groups, it could be concluded that the opinions of the different respondent groups on the main budgeting goals differ; hence, the views of the different groups of respondents on the compliance of the specific objectives with the main budgeting goal differ. There exists a moderate correlation $|\mathrm{r}=0.53|$ among the groups of respondents of the small companies and their replies regarding the compliance of the specific objective with the main budgeting goal PD. Furthermore, in accordance with the data, the lower is a position of the respondent in the company the more he/she considers the $P D$ as the main budgeting goal. That indicates that the managers and the staff of financial departments, in contrary to the views of business owners and managers, consider this objective as one of the main budgeting goals.
An analysis of the correlation among the main budgeting goals leads the author to the conclusion that most of the objectives are interrelated, however, the correlation in the category of all enterprises and in the category of micro-small enterprises is very weak $0<|\mathrm{r}|<0.2$ or weak $0.2 \leq|\mathrm{r}|<050$. There exists a moderate correlation $|\mathrm{r}=0.60|$ between two budgeting objectives - ISS and IEB referred to by the respondents of the micro enterprises. In the small enterprises, a few moderate correlations between the main budgeting goals could be found: a moderate correlation $|\mathrm{r}=0.64|$ between $P D$ and $I M S$; a moderate correlation between $I R$ and, consecutively, IP $|\mathrm{r}=0.57|, I E P-|\mathrm{r}=0.51|, I M S-|\mathrm{r}=0.61|, I S S-|\mathrm{r}=0.61|$, and $I Q-|\mathrm{r}=0.61|$.

The evaluation of the importance of the financial and non-financial indicators for the assessment of the company's business activities/performance provided by the respondents allows conducting the factor analysis of the financial and non-financial indicators establishing interconnections between the indicators. In the result of the analysis, three factor groups of financial indicators and two factor groups of nonfinancial indicators, considered by the respondents as important and affecting business performance, were established (Table 3 ).

TABLE 3.

RESULTS OF JOINT FACTOR ANALYSIS OF FINANCIAL AND NON-FINANCIAL INDICATORS IN THE CATEGORY "ALL ENTERPRISES"

\begin{tabular}{|c|c|c|c|c|c|c|c|c|c|}
\hline \multicolumn{6}{|c|}{ Financial indicators } & \multicolumn{4}{|c|}{ Non-financial indicators } \\
\hline \multicolumn{10}{|c|}{ Labels and codes of factor groups } \\
\hline $\begin{array}{c}\text { Solvency and } \\
\text { profitability / } \\
\text { F-SP }\end{array}$ & Code & $\begin{array}{l}\text { Efficiency of assets } \\
\text { use and financial } \\
\text { stability / } \\
\text { F-ES }\end{array}$ & Code & $\begin{array}{c}\text { Evaluation of } \\
\text { investment } \\
\text { possibilities } \\
\text { F-I }\end{array}$ & Code & $\begin{array}{l}\text { Role and } \\
\text { influence of } \\
\text { employees / } \\
\text { NF-E }\end{array}$ & Code & $\begin{array}{l}\text { Role and } \\
\text { influence of } \\
\text { consumers / } \\
\text { NF-C }\end{array}$ & Code \\
\hline Cash-flow report & F2 & Net turnover & F1 & $\begin{array}{l}\text { Return on } \\
\text { investments } \\
\text { (ROI) }\end{array}$ & F14 & $\begin{array}{l}\text { Motivated } \\
\text { employees }\end{array}$ & NF5 & $\begin{array}{ll}\text { Level } & \text { of } \\
\text { consumers } & \\
\text { satisfaction } & \end{array}$ & NF1 \\
\hline Current ratio & F3 & $\begin{array}{l}\text { Asset turnover, } \\
\text { times }\end{array}$ & F4 & & & $\begin{array}{l}\text { Loyal } \\
\text { employees }\end{array}$ & NF6 & \begin{tabular}{|lr} 
Increase & of \\
number & of \\
consumers & \\
\end{tabular} & NF2 \\
\hline $\begin{array}{l}\text { Debt-to-equity } \\
\text { ratio }\end{array}$ & F9 & \multirow{2}{*}{$\begin{array}{l}\text { Accounts receivable } \\
\text { turnover } \\
\text { times) }\end{array}$} & \multirow[t]{2}{*}{ F5 } & \multirow{2}{*}{$\begin{array}{l}\text { EBIIMS } \\
\text { (TD)A } \\
\text { profitability }\end{array}$} & \multirow[t]{2}{*}{ F15 } & \multirow{2}{*}{$\begin{array}{l}\text { The level of } \\
\text { employees } \\
\text { satisfaction }\end{array}$} & \multirow[t]{2}{*}{ NF7 } & $\begin{array}{l}\text { Consumers } \\
\text { loyalty }\end{array}$ & NF3 \\
\hline Gross profitability & F10 & & & & & & & \multirow{2}{*}{$\begin{array}{l}\text { Quality of the } \\
\text { products } \\
\text { services }\end{array}$} & \multirow[t]{2}{*}{ NF4 } \\
\hline $\begin{array}{l}\text { Return on assets } \\
\text { (ROA) }\end{array}$ & F11 & $\begin{array}{l}\text { Inventory turnover } \\
\text { (days/times) }\end{array}$ & F6 & \multirow{3}{*}{$\begin{array}{l}\text { DSCR (debt } \\
\text { service } \\
\text { coverage } \\
\text { ratio) }\end{array}$} & \multirow[t]{3}{*}{ F16 } & \multirow{2}{*}{$\begin{array}{l}\text { Development of } \\
\text { new products / } \\
\text { services }\end{array}$} & \multirow[t]{2}{*}{ NF8 } & & \\
\hline $\begin{array}{l}\text { Return on equity } \\
\text { (ROE) }\end{array}$ & $\mathrm{F} 12$ & $\begin{array}{l}\text { Payables turnover } \\
\text { (days/times) }\end{array}$ & F7 & & & & & $\begin{array}{l}\text { Company } \\
\text { reputation }\end{array}$ & NF10 \\
\hline $\begin{array}{l}\text { Return on sales } \\
\text { (ROS) }\end{array}$ & F13 & $\begin{array}{l}\text { Total debt ratio in } \\
\text { the balance }\end{array}$ & F8 & & & $\begin{array}{l}\text { Training of } \\
\text { employees }\end{array}$ & NF9 & Market share & NF11 \\
\hline
\end{tabular}

The results of the regression analysis between the financial/non-financial factor groups and the main budgeting objectives in accordance with the enterprise categories leads to the conclusion that a statistically reliable result in the micro-small companies exists between the budgeting goal IEB and the importance of the factor group "Role and influence of employees"
(NF-E). The budgeting objective IEB affects a significance level of the $N F-E$ factor group by $6 \%$. Larger number of interrelated impact of the budgeting goals and the factor groups could be observed in the small and micro enterprises, hence, the author has summarised possible impact of the financial/ non- 
financial factor groups and the main budgeting goals in the small and micro enterprises in Table 4 .

TABLE 4.

POSSIBLE IMPACT $\left(\mathrm{R}^{2}\right)$ BETWEEN THE FINANCIAL AND NON-FINANCIAL FACTOR GROUPS (DEPENDENT VARIABLE) AND THE MAIN BUDGETING OBJECTIVES (INDEPENDENT VARIABLE) IN THE SMALL AND MICRO ENTERPRISES (\%).

\begin{tabular}{|c|c|c|c|c|c|c|c|c|c|c|c|c|c|c|c|c|c|c|c|c|c|c|}
\hline \multirow{4}{*}{$\begin{array}{l}\text { Factor } \\
\text { groups }\end{array}$} & \multicolumn{22}{|c|}{ Main budgeting objectives } \\
\hline & \multicolumn{2}{|c|}{ AR } & \multicolumn{2}{|c|}{ IT } & \multicolumn{2}{|c|}{ IP } & \multicolumn{2}{|c|}{ IEP } & \multicolumn{2}{|c|}{ IEB } & \multicolumn{2}{|c|}{ ICS } & \multicolumn{2}{|c|}{ IMS } & \multicolumn{2}{|c|}{ ISS } & \multicolumn{2}{|c|}{ IQ } & \multicolumn{2}{|c|}{ PD } & \multicolumn{2}{|c|}{ IR } \\
\hline & \multicolumn{22}{|c|}{ Enterprise categories* } \\
\hline & 1 & 2 & 1 & 2 & 1 & 2 & 1 & 2 & 1 & 2 & 1 & 2 & 1 & 2 & 1 & 2 & 1 & 2 & 1 & 2 & 1 & 2 \\
\hline F-SP & & 5 & 9 & & 19 & 5 & 8 & & & & & & & & & & & & & 5 & & 5 \\
\hline F-ES & & 12 & & & & & & & 21 & & & 14 & 8 & & & & & & & & & 18 \\
\hline F-I & 21 & & & & 22 & & & 9 & & & & 7 & 8 & & & & & & 7 & & 8 & 16 \\
\hline NF-E & & 5 & & & & 14 & 15 & & & & & & & & & & 18 & & & & & \\
\hline NF-C & & & & & & & & & & & & & & & & & 10 & & & & & \\
\hline
\end{tabular}

Designations: $* 1-$ small enterprises, 2 - micro enterprises

In the small enterprises, more significant possible influence is observed regarding four out of the eleven budgeting goals - IP; IEP; IMS and $I Q$ that determine the importance of two out of the five factor groups in the achievement of these goals. The budgeting objective $I P$ has the major impact on the $F-I$ factor group and determines its importance by $22 \%$. Higher potential effect could been observed with regard to the budgeting $I Q$ objective, which impacts the $N F-E$ factor group and determines its importance by $18 \%$.

In the micro enterprises, higher potential influence is observed in respect of two out of the eleven budgeting goals $-A R$ and $I R$, which determine the importance of three out of the five factor groups in the achievement of these goals. The highest impact these goals have on the $F$-ES factor group and, respectively, determine their importance by $12 \%$ and $18 \%$.
The results of the multiple regression analysis between the financial and non-financial factor groups and the main budgeting goals in accordance with the enterprise categories lead to the conclusion that the importance of the $N F-E$ factor group indicators in the micro-small companies is influenced by $13 \%$, and only one variable - the budgeting objective $I E B$ - is statistically significant. In the small and micro enterprises, a higher number of statistically significant variables, influencing the importance of the factor groups indicators, can be observed. Therefore, the author has compiled Table 5, summarizing possible impact between financial and non-financial factor groups and the main budgeting objectives in the small and micro companies, considering statistical reliability.

TABLE 5.

STATISTICAL RELIABILITY OF THE RESULTS OF THE MULTIPLE REGRESSION ANALYSIS OF THE FACTOR GROUPS OF FINANCIAL AND NON-FINANCIAL INDICATORS (DEPENDENT VARIABLE) AND THE MAIN BUDGETING OBJECTIVES (INDEPENDENT VARIABLE) IN THE SMALL AND MICRO ENTERPRISES

\begin{tabular}{|c|c|c|c|c|c|c|c|c|c|c|c|c|c|c|c|c|c|c|c|c|c|c|c|c|}
\hline \multirow{4}{*}{$\begin{array}{l}\text { Factor } \\
\text { groups }\end{array}$} & \multicolumn{22}{|c|}{ Main budgeting objectives } & \multirow{2}{*}{\multicolumn{2}{|c|}{$\begin{array}{l}\text { Possible impact } \\
\left(\mathbf{R}^{2)}\right.\end{array}$}} \\
\hline & \multicolumn{2}{|c|}{ AR } & \multicolumn{2}{|c|}{ IT } & \multicolumn{2}{|c|}{ IP } & \multicolumn{2}{|c|}{ IEP } & \multicolumn{2}{|c|}{ IEB } & \multicolumn{2}{|c|}{ ICS } & \multicolumn{2}{|c|}{ IMS } & \multicolumn{2}{|c|}{ ISS } & \multicolumn{2}{|c|}{ IQ } & \multicolumn{2}{|c|}{ PD } & \multicolumn{2}{|c|}{ IR } & & \\
\hline & \multicolumn{24}{|c|}{ Enterprise categories* } \\
\hline & 1 & 2 & 1 & 2 & 1 & 2 & 1 & 2 & 1 & 2 & 1 & 2 & 1 & 2 & 1 & 2 & 1 & 2 & 1 & 2 & 1 & 2 & 1 & 2 \\
\hline F-SP & $\sqrt{ }$ & $\sqrt{ }$ & & & $\sqrt{ }$ & & $\sqrt{ }$ & & $\sqrt{ }$ & & & & & & & & & & & & & & 0.37 & 0.17 \\
\hline F-ES & & & $\sqrt{ }$ & $\sqrt{ }$ & $\sqrt{ }$ & & & & $\sqrt{ }$ & & & $\sqrt{ }$ & & $\sqrt{ }$ & $\sqrt{ }$ & & & & $\sqrt{ }$ & & & $\sqrt{ }$ & 0.50 & 0.36 \\
\hline F-I & $\sqrt{ }$ & & $\sqrt{ }$ & & $\sqrt{ }$ & & $\sqrt{ }$ & & $\sqrt{ }$ & & $\sqrt{ }$ & & $\sqrt{ }$ & & $\sqrt{ }$ & & $\sqrt{ }$ & & $\sqrt{ }$ & & $\sqrt{ }$ & & 0.73 & 0.25 \\
\hline NF-E & $\sqrt{ }$ & $\sqrt{ }$ & $\sqrt{ }$ & & & $\sqrt{ }$ & & & & & & & $\sqrt{ }$ & & & & $\sqrt{ }$ & & $\sqrt{ }$ & & & & 0.58 & 0.29 \\
\hline NF-C & & & & $\sqrt{ }$ & $\sqrt{ }$ & $\sqrt{ }$ & $\sqrt{ }$ & $\sqrt{ }$ & $\sqrt{ }$ & $\sqrt{ }$ & $\sqrt{ }$ & & & $\sqrt{ }$ & $\sqrt{ }$ & & $\sqrt{ }$ & & & & $\sqrt{ }$ & & 0.54 & 0.19 \\
\hline
\end{tabular}

Designations: $* 1$-small enterprises, 2 -micro enterprises, $\sqrt{ }$-statistical significance

The multiple regression analysis of the impact of the budgeting objectives in the small enterprises on the significance of the factor groups indicators points out (Table 5) that the importance of the $F-I$ factor group indicators are determined by $73 \%$, and all of the main budgeting objectives are statistically significant. The main budgeting goals influence the importance of the $N F-C$ factor group indicators by $54 \%$, and seven out of the eleven budgeting objectives (IP, IEP, IEB, $I C S, I S S, I Q, I R)$ are considered to be statistically significant.

In the micro enterprises, in comparison with the small enterprises, the impact of the main budgeting objectives on the importance of the factor group indicators are essentially lower; the highest impact can be observed regarding the importance of the F-ES 
factor group indicators $(36 \%)$, where four out of the eleven budgeting objectives (IT, ICS, IMS, IR) are significant.

Consistent with the results of the regression analysis of the particular financial indicators within the factor group and the main budgeting objectives in accordance with the enterprise category, it can be concluded that a statistically reliable result in the category of all enterprises exists between the budgeting objective $I E P$ and the importance of the indicator $F 3$. The budgeting objective IEP affects the importance level of the indicator $F 3$ by $6 \%$. In the micro-small enterprises, the statistically significant result exists between the budgeting objective $A R$ and the indicator $F 15$, the influence is by $5 \%$. In the small and micro enterprises, a higher number of interrelated effects between the budgeting objectives and the financial indicators can be observed, therefore, the author has compiled Table 6 to summarise the possible impact between the financial indicators and the main budgeting objectives in the small and micro enterprises.

In the small companies, a higher possible impact is observed regarding the budgeting objective $I P$, which determines the importance of eight out of the sixteen financial indicators in the achievement of this objective. The highest impact of this objective is on the indicator $F 15$ and determines its importance by $31 \%$. In the small enterprises, the highest possible impact is observed as well regarding the objectives $I E B$ and $I R$, which determine the importance of six out of the sixteen financial indicators in the achievement of this objective. The highest impact on the financial indicator F9 is determined by the budgeting objective $I E B$, affecting its importance by $31 \%$. The budgeting objective $I R$ affects the financial indicator $F 11$ and determines its importance by $19 \%$.

In the micro enterprises, the highest potential impact is observed regarding the budgeting objective $I R$, which determines the importance of ten out of the sixteen financial indicators in the achievement of this objective. The highest impact of this objective is on the financial indicator $F 4$, determining its importance by $29 \%$. In the micro enterprises, higher possible impact is observed as well regarding the financial objective $A R$, which determines the importance of eight out of the sixteen financial indicators in the achievement of this objective. The highest impact of this objective is on the financial indicator F8, determining its importance by $12 \%$.

TABLE 6.

POSSIBLE IMPACT $\left(\mathrm{R}^{2}\right)$ BETWEEN THE FINANCIAL INDICATORS (DEPENDENT VARIABLE) AND THE MAIN BUDGETING OBJECTIVES (INDEPENDENT VARIABLE) IN THE SMALL AND MICRO ENTERPRISES (\%).

\begin{tabular}{|c|c|c|c|c|c|c|c|c|c|c|c|c|c|c|c|c|c|c|c|c|c|c|c|}
\hline \multirow{4}{*}{$\begin{array}{l}\text { Factor } \\
\text { groups }\end{array}$} & \multirow{4}{*}{ Code } & \multicolumn{22}{|c|}{ Main budgeting objectives } \\
\hline & & \multicolumn{2}{|l|}{$\mathrm{AR}$} & \multicolumn{2}{|l|}{ IT } & \multicolumn{2}{|l|}{ IP } & \multicolumn{2}{|c|}{ IEP } & \multicolumn{2}{|l|}{ IEB } & \multicolumn{2}{|c|}{ ICS } & \multicolumn{2}{|c|}{ IMS } & \multicolumn{2}{|l|}{ ISS } & \multicolumn{2}{|l|}{ IQ } & \multicolumn{2}{|l|}{$\mathrm{PD}$} & \multicolumn{2}{|l|}{ IR } \\
\hline & & \multicolumn{22}{|c|}{ Enterprise categories* } \\
\hline & & 1 & 2 & 1 & 2 & 1 & 2 & 1 & 2 & 1 & 2 & 1 & 2 & 1 & 2 & 1 & 2 & 1 & 2 & 1 & 2 & 1 & 2 \\
\hline \multirow{7}{*}{ F-SP } & $\mathrm{F} 2$ & & & & & 12 & & & & & & 9 & & 22 & & & & & & 11 & 8 & & \\
\hline & F3 & & & & 13 & & & & 13 & & & & 6 & & 6 & & & 21 & & & 10 & & \\
\hline & F9 & & 7 & & & & & & & 31 & 5 & & 5 & & & & & 12 & & & & & 10 \\
\hline & F10 & & & & & 20 & & 10 & & & & 9 & & & 8 & 7 & & 7 & & & & 7 & \\
\hline & F11 & & & 12 & & 26 & 16 & 22 & 6 & & & & & & & & & & & & & 19 & 5 \\
\hline & F12 & & & 16 & & 13 & & & & & & & & & & & & & & & & & \\
\hline & F13 & & & & & 17 & 6 & 13 & 8 & & & 8 & & & & & & & & & 10 & & \\
\hline \multirow{6}{*}{ F-ES } & F1 & & 8 & & & & 10 & & & & & & & & 15 & & & & & 14 & & & \\
\hline & F4 & & 5 & & & & & & & 27 & & & & & & 12 & & & & & & & 29 \\
\hline & F5 & & 5 & & & & & & & 17 & & & 5 & 16 & & & & & & & & 7 & \\
\hline & F6 & & 7 & & & & & & & 27 & & & 12 & 12 & & & & & & & & & 17 \\
\hline & F7 & & 6 & & 5 & 7 & & & & 9 & & 12 & & & & & & & & & 5 & & 11 \\
\hline & F8 & & 12 & & & & & & & 12 & 9 & & 10 & & & & & & & & & 10 & 9 \\
\hline \multirow{3}{*}{ F-I } & F14 & 11 & & 16 & & 14 & & 13 & 7 & & & & 5 & 15 & & & 5 & & & 25 & & 15 & 10 \\
\hline & F15 & 18 & & & 9 & 31 & 6 & & 14 & & & & & 14 & 6 & & & & & & 6 & 14 & 8 \\
\hline & F16 & 15 & 8 & & & & & & & & & & 7 & & & & & 8 & & & & & 17 \\
\hline
\end{tabular}

Designations: * 1- micro enterprises, 2 - small enterprises

The comparison of the possible effects between the financial indicators and the main budgeting goals in the small and micro enterprises leads to the conclusion that the budgeting objectives of the small companies are of larger influence on the importance level of the financial indicators.

Evaluation of the results of the regression analysis of the non-financial indicators (dependent variable) and the main budgeting objectives (independent 
variable) in accordance with the enterprise category leads to the conclusion that, in the micro-small companies, a statistically significant result exists between the budgeting objective $I E B$ and the nonfinancial indicator $N F 8$. The objective $I E B$ determines the level of importance of the indicator $N F 8$ by $5 \%$. A larger number of interrelated influences between the budgeting objectives and non-financial indicators are observed in the small and micro enterprises, therefore, the author has compiled Table 7 to summarize the potential impact between the non-financial indicators and the main budgeting objectives in the small and micro enterprises.

TABLE 7.

POTENTIAL IMPACT $\left(\mathrm{R}^{2}\right)$ BETWEEN THE NON-FINANCIAL INDICATORS (DEPENDENT VARIABLE) AND THE MAIN BUDGETING OBJECTIVES (INDEPENDENT VARIABLE) IN THE SMALL AND MICRO ENTERPRISES (\%)

\begin{tabular}{|c|c|c|c|c|c|c|c|c|c|c|c|c|c|c|c|c|c|c|c|c|c|c|c|}
\hline \multirow{4}{*}{$\begin{array}{l}\text { Factor } \\
\text { groups }\end{array}$} & \multirow{4}{*}{ Code } & \multicolumn{22}{|c|}{ Main budgeting objectives } \\
\hline & & \multicolumn{2}{|c|}{ AR } & \multicolumn{2}{|c|}{ IT } & \multicolumn{2}{|c|}{ IP } & \multicolumn{2}{|c|}{ IEP } & \multicolumn{2}{|c|}{ IEB } & \multicolumn{2}{|c|}{ ICS } & \multicolumn{2}{|c|}{ IMS } & \multicolumn{2}{|c|}{ ISS } & \multicolumn{2}{|c|}{ IQ } & \multicolumn{2}{|c|}{ PD } & \multicolumn{2}{|c|}{ IR } \\
\hline & & \multicolumn{22}{|c|}{ Enterprise categories* } \\
\hline & & 1 & 2 & 1 & 2 & 1 & 2 & 1 & 2 & 1 & 2 & 1 & 2 & 1 & 2 & 1 & 2 & 1 & 2 & 1 & 2 & 1 & 2 \\
\hline \multirow{5}{*}{ NF-E } & NF5 & & 11 & & 7 & 8 & 7 & 21 & 10 & 21 & 7 & & & & & & & 21 & & & 6 & & \\
\hline & NF6 & & 6 & & & & & 22 & 9 & & 7 & & & & & & & 12 & & & 5 & & \\
\hline & NF7 & & & & & & 16 & & & & & & & & & & 10 & 21 & 5 & & & & \\
\hline & NF8 & & & 7 & & & 8 & & & & & & & & & & & & & 19 & 7 & & \\
\hline & NF9 & 7 & & 13 & & & 14 & 7 & & & & & & 10 & & & & 9 & & & & 7 & \\
\hline \multirow{6}{*}{ NF-C } & NF1 & & & & & 10 & 9 & & & & & 7 & & & & & & 17 & & 15 & & & \\
\hline & NF2 & & & & & & & & & & & & & & & 14 & & & & & & & \\
\hline & NF3 & & 11 & 7 & 19 & 15 & & 8 & 6 & & & & & 15 & & & & 15 & & & & & \\
\hline & NF4 & & & & & & & & & & & & & & & & & & & & & & \\
\hline & NF10 & & 7 & & 6 & & & 13 & & & 16 & 9 & & 11 & & & & & & 7 & 6 & & \\
\hline & NF11 & & & & & & & & & 23 & & & & & & 37 & & & & & & & \\
\hline
\end{tabular}

In the small enterprises, more significant possible influence is observed regarding the budgeting objective $I Q$, which determines the importance of six out of the eleven non-financial indicators in the achievement of this objective. The highest impact by this objective is on the non-financial indicators NF5 and $N F 7$, determining their importance by $21 \%$. In the small enterprises, a larger potential effect is observed as well regarding the budgeting objective IEP, which determines the importance of five out of the eleven non-financial indicators in the achievement of this objective. The highest is the impact of this objective on the non-financial indicator NF6, determining its importance by $22 \%$. The influence of the budgeting objective ISS on the importance of the non-financial indicator NF11 should be emphasized, as it has produced a statistically significant result $-37 \%$.In the micro enterprises, the highest potential impact is observed in relation to the budgeting objective $I P$, which determines the importance of five out of the eleven non-financial indicators in the achievement of this objective. The highest influence of this objective is on the non-financial indicator $N F 7$, determining its importance by $16 \%$.

The comparison of the extent of the possible impact of the main budgeting goals on the non-financial indicators in the small and micro enterprises, it can be concluded that the probable influence on the non- financial indicators are higher in the small enterprises. In its turn, the comparison of the potential impact on the financial/ non-financial indicators by the main budgeting goals, leads to the conclusion that, generally, the main budgeting objectives have higher possible impact on the importance of the financial rather than non-financial indicators.

The practical research is under the development; in the result of the study, a system of the business performance assessment indicators will be developed providing the managers of the companies with a possibility to evaluate and monitor performance of the company in an integrated and efficient way.

\section{CONCLUSION}

The opinions among the respondent groups regarding the main budgeting goals of the companies differ. In the small enterprises, a moderate correlation between the respondent groups and their answers regarding the compliance of the specific objective with the main budgeting goal - development of new products/services (PD) - exists, demonstrating that the managers and staff of financial departments, as opposed to the business owners and managers, consider this objective to be one of the main budgeting goals of the company. 
There are correlations between the main budgeting objectives of the companies. In the small enterprises, a moderate correlation exists between the goal related to the development of new products/services and the goal related to the increase of the market share of the company. Furthermore, moderate correlations are observed between the budgeting objective related to the improvement of the corporate image and the budgeting objectives related to the increase of profits, increase of profitability and efficiency, increase of the market share, increase of the employees' satisfaction, improvement of the quality of products and services.

In the small enterprises, a higher possible impact is observed as regards four out of the eleven main budgeting objectives: increase of profits, increase of profitability and efficiency, increase of the market share, and the improvement of the products/services quality; these four determine the importance of two out of the five factor groups in the achievement of these objectives. The highest impact of the budgeting objective related to the profit increase is on the factor group F-I, determining its importance by $22 \%$. A higher potential impact is also observed regarding the budgeting objective related to the products/services quality improvement, which determines the importance of the factor group NF-ISS by $18 \%$.

The comparison of the possible influences between the financial/ non-financial factor groups and the main budgeting objectives in the small and micro enterprises leads to the conclusion that the potential influence is larger in the small enterprises.

The overall impact of the main budgeting objectives on the importance of the F-I financial group indicators comprises $73 \%$, and all of the main budgeting objectives are statistically significant. The overall impact of the budgeting objectives on the importance of the non-financial factor group NF-E indicators comprises $54 \%$, and seven out of the eleven main budgeting objectives (IP, IEP, IEB, ICS, ISS,IQ, IR) are statistically significant.

In the small enterprises, the main budgeting objectives have a larger potential impact on the importance level of the financial and non-financial indicators if compared with the other enterprise categories being examined. The comparison of the possible impact of the main budgeting objectives on the importance level of the financial indicators and the non-financial indicators leads to the conclusion that the larger possible impact is related to the importance of the financial rather than non-financial indicators.

\section{REFERENCES}

[1] Berger, P.L., Luckmann, T.L. The Social Construction of Reality. Doubleday. Garden City, NY, 1966.

[2] Cardinaels, E., Van Veen-Dirks, P.M.G. Financial versus nonfinancial information: The impact of information organization and presentation in a Balanced Scorecard. Accounting, Organizations and Society, 35, 2010, pp.565-578.

[3] Coram, P.J., Mock, T.J., Monroe, G.S. Financial analysts' evaluation of enhanced disclosure of non-financial performance indicators. The British Accounting Review, 43(2), 2011, pp.87-101.

[4] Craig, J., Moores, K. Balanced Scorecards to drive the strategic planning of family firms. Family business review, XVIII (2), 2005, pp.105-122.

[5] Fernandes, K.J., Raja, V., Whalley, A. Lessons from implementing the balanced scorecard in a small and medium size manufacturing organization. Technovation, 26, 2006, pp.623-634.

[6] Folan, P., Browne, J. A review of performance measurement: Towards performance management. Computers in Industry, 56, 2005, pp.663.-680.

[7] Folan, P., Browne, J., Jagdev, H. Performance: Its meaning and content for today's business research. Computers in Industry, 58, 2007, pp.605.-620.

[8] Hoque, Z. Linking environmental uncertainty to non-financial performance measures and performance: a research note. The British Accounting Review, 37, 2005, 471-481.

[9] Jansons, V., Kozlovskis, K. Ekonomiskā prognozēšana SPSS 20 vidē. Rīga: RTU Izdevniecība, 2012.

[10] Kotane, I. The role of the analysis of financial and nonfinancial indicators in assessment of performance of the companies. Management theory and studies for rural business and infrastructure development, 34, 2012, pp.93.-104.

[11] Kotane, I. The evaluation of financial and non-financial indicators in evaluating the performance of company. Latgale national economy research, 5, 2013, pp.129.-147.

[12] Kotane, I., Kuzmina-Merlino, I. Non-financial indicators for evaluation of business activity. European integration studies, 5, 20111, pp.213.-219

[13] Kotane, I., Kuzmina-Merlino, I. Assessment of financial indicators for evaluation of business performance. European integration studies, 6, 2012, pp.216.-224.

[14] Krumwiede, K.R., Swain, M.R., Thornock, T.A., Eggett, D.L. The effects of task outcome feedback and broad domain evaluation experience on the use of unique scorecard measures. Advances in Accounting, 29(2), 2013, pp. 205-217.

[15] Laitinen, E.K. A dynamic performance measurement system: evidence from small Finish technology companies. Scandinavian Journal of Management, 18(1), 2002, pp. 65-99.

[16] Lebas, M.J. Performance measurement and performance management. International Journal of Production Economics, 41(1-3), 1995, pp.23.-35

[17] Liepa, I. Biometrija. Rīga, Zvaigzne, 1974.

[18] Neely, A., Gregory, M. and Platts, K. Performance measurement system design. A literature review and research agenda. International Journal of Operations \& Production Management, 25(12), 2005, pp.1228-1263.

[19] Phillips, P., Louvieris, P. Performance measurement systems in tourism, hospitality and leisure small medium-sized enterprises: a balanced scorecard perspective. Journal of Travel Research, 44, 2005, pp.201-211.

[20] Prieto, I.M., Revilla, E. Learning capability and business performance: a non-financial and financial assessment. Learning Organization, 13(2), 2006, pp.166 - 185.

[21] Susilawati, A.,Tan, J., Bell, D. and Sarwar, M. Develop a framework of performance measurement and improvement system for lean manufacturing activity. International Journal of Lean Thinking, 4(1), 2013, pp.51.-64.

[22] Taticchi, P., Tonelli, F. and Cagnazzo, L. Performance measurement and a management: a literature review and a research agenda. Measuring Business Excellence, 14(1), 2010, pp.4.-18,

[23] Uyar, A. Development of non-financial measures as contemporary performance measurement tools. World of Accounting Science, 12(1), 2010, pp.209-238.

[24] Watts, T., McNair-Connolly, C.J. New Performance Measurement and Management Control Systems. Journal of Applied Acounting Research, 13(3), 2012, pp.226.-241.

[25] Wen, W., Chen, Y.H., Chen, I.C. A knowledge-based decision support system for measuring enterprise performance. Knowledge-Based Systems, 21(2), 2008, pp.148.-163. 
Inta Kotane / Environment. Technology. Resources, (2015), Volume II, 158-167

[26] Winstanley, D., Stuart-Smith, K. Policing performance: the ethics of performance management. Personnel Review, 25(6), 1996, pp.66.-84.
[27] Zeng, S.X., Meng, X.H., Yin, H.T., Tam, C.M., Sun, L. Impact of cleaner production on business performance. Journal of Cleaner Production, 18(10-11), 2010, pp.975-983. 